\title{
COMPARISON OF THE MICROTENSILE BOND STRENGTH OF FOUR
DIFFERENT BULK-FILL RESIN COMPOSITES OF CLASS I CAVITIES WITH
DENTIN
}

\section{ABSTRACT}

Objectives: The aim of this study is to compare the microtensile bond strengths of four different bulk-fill composites and a microhybrid composite to the dentin.

Materials and methods: 4 bulk-fill composites and a microhybrid composite were tested. Class I occlusal cavities were prepared on 25 freshly drawn intact human molar teeth, randomly divided into five groups [G-aenial posterior (Control group), Estelite Bulk Fill flow, GrandioSO x-tra, Beautifil Bulk Restorative, FillUp] and the cavities were restorated with five composite systems by using their own adhesive systems. Completed restoration teeth bukkolingual and mesiodistal sections were taken, three samples were obtained from each tooth. Microtensile bond strength values of groups were measured by universal test machine. Microscopic changes were examined by SEM. The data were evaluated by oneway ANOVA and Tukey tests.

Results: While the control group showed the highest microtensile bond strength, Fill-Up group showed the lowest. The control group was statistically significant when compared to the four different bulk-fill groups used in the study $(\mathrm{p}<0.05)$. Although the GrandioSO x-tra group showed the highest bonding strength among the bulk-fill composites, the differences between the Beautifil Bulk Restorative and Estelite Bulk Fill flow were statistically insignificant $(p>0.05)$. Fill-Up was found to be statistically significant when compared to the other bulk-fill groups $(\mathrm{p}<0.05)$. In SEM analyzes a regular gap is seen along the hybrid layer only in Estelite Bulk Fill flow.

Conclusions: No bulk-fill composite group could reach the value of the bond strength of microhybrid composite. Although the Fill-Up group was used with the etch and rinse adhesive system among the bulk-fill composites, it showed the lowest bond strength.

Keywords: Bulk-fill composites, microtensile bond strength, dentin
*Serra Kutlu

İhsan Hubbezoğlu

ORCID IDs of the authors:

S.K. 0000-0001-5127-0885

İ.H. 0000-0001-8984-9286

Department of Restorative Dentistry, Faculty of Dentistry, Sivas Cumhuriyet University, Sivas, Turkey.

Received : : 30.07.2019 Accepted $: 24.08 .2019$ 


\section{INTRODUCTION}

Nowadays, composite resins in dentistry are clinically frequently applied with the development of composite resin and adhesive systems over the years and increased aesthetic expectations of patients. ${ }^{1}$ The popularity of light curing composites is due to their aesthetic, biocompatibility and wear resistance properties. However, it is still an unsolved problem to keep the polymerization shrinkage and the clinical performance of restoration in the resin composite restorations. Different clinical methods have been developed to reduce the shrinkage stress during polymerization, such as adjusting the mode and intensity of the light device, applying a flowable resin composite under the material and applying incrementally. ${ }^{2-4}$ Hardening of the composite; It is also influenced by factors such as the monomer content of the material, reaction initiators, hue, opacity, wavelength, intensity of light, distance from light device and exposure time. Insufficient light penetration causes the reaction to not complete under the material. For this reason, light curing resin composites have been applied by incremental technique since they are produced. ${ }^{5}$ The application of resin composite by incremental technique causes time loss especially in the posterior region, increases the risk of space between the layers and this method adversely affects the success of the restoration while increasing the risk of contamination. ${ }^{6}$

One of the most recently developed restorative materials is bulk-fill resin composites applied as a single layer in the posterior region. Bulk-fill composites placed in a single layer up to a depth of $4 \mathrm{~mm}$ took their place in dental markets. The barium and yiterbium particles in the structure increase the radiopacity of the material and allow the effect of the light device to reach deep. ${ }^{7}$ Bulkfill resin composites as well as flowable bulk-fill composites are one of the most up to date materials on the market. Flowability allows these materials to be easily adapted to cavity walls. ${ }^{8}$ These materials, which are reported to reduce the possibility of deformation, postoperative sensitivity, microleakage and secondary caries with low polymerization shrinkage, increase the comfort of patient and physician by applying these materials at once. ${ }^{9,10}$

In order to minimize the clinical aesthetics of glass ionomer cements such as poor aesthetic results and moisture related effects, giomers are defined as resin-based restorative material containing fluorine release and PRG fillers. ${ }^{11,12}$ In the content of giomers; Bis-GMA, TEGDMA, inorganic glass filler, aluminum oxide, silica, PRG filler and DLcamphorquinone. ${ }^{13}$ Composite resins containing SPRG filler exhibit antibacterial activity by releasing metal ions from the composite. ${ }^{14}$ The strontium and fluorine convert the hydroxyapatite into stronsiapatite and fluoroapatite to ensure that the tooth is resistant to acid. In addition, S-PRG fillers change the $\mathrm{pH}$ of the surrounding environment when in contact with water or acidic solutions. ${ }^{15}$

It is used in order to obtain preliminary information about bond strength tests, restoration materials activities and clinical success of adhesive systems. ${ }^{16,17}$ The microtensile bond strength test ( $\mu$ TBS) was first proposed by Sano in 1994. With this test method, the bond strength can be measured in an area of approximately $1 \mathrm{~mm}^{2}$ of dentin, and a large number of samples can be prepared from a single tooth. ${ }^{18}$

The aim of this study is to evaluate the microtensile bond strengths of 2 flowable, 2 condensable bulk-fill composite resins to the dentin compared to a conventional microhybrid composite.

\section{MATERIALS AND METHODS}

\section{Selection of Teeth}

The study was initiated by the Non-Interventional Clinical Research Ethics Committee of Sivas Cumhuriyet University with the approval of the Ethics Committee dated 26.02.2018 and numbered 2018-01/11. In this study, 25 permanent human molar teeth extracted for orthodontic or periodontal reasons in last 6 months in the Department of Oral and Maxillofacial Surgery, Faculty of Dentistry, Sivas Cumhuriyet University were used. Immediately after extraction, the teeth were kept in $2.5 \%$ sodium hypochlorite $(\mathrm{NaOCI})$ solution for 1 hour and the organic residues on the crown surface were removed. The teeth were then soaked in distilled water at room temperature until all the 
teeth were collected and the study started, and the storage fluid was changed every week.

\section{Preparation of Dental Specimens}

25 human molar teeth to be subjected to microtensile bond strength test were buried into the L shaped mold using silicon self-curing acrylic (IMICRYL Dental, Konya, Turkey).

\section{Establishment of Working Groups}

On each molar, occlusal class I cavities (approximately $3.5 \mathrm{~mm}$ wide and $4 \mathrm{~mm}$ deep) were prepared using a high speed handpiece and diamond burs (Dia-burs, Mani, Japan, SF-41C, Coarse) with air and water coolant. Tooth samples were randomly divided into five groups $(n=5)$, according to the type of composite used for restoring class I cavities. Five groups were formed according to the composite resin materials used in this study (Table 1). The total number of samples is 75 .

Table 1. Materials tested and their composition

\begin{tabular}{|c|c|c|c|}
\hline Groups & Composites & Composition & Adhesive system \\
\hline $\begin{array}{l}\text { Group } 1 \\
\text { (Control } \\
\text { group) }\end{array}$ & $\begin{array}{l}\text { G-aenial posterior } \\
\text { (GC, Japan) }\end{array}$ & $\begin{array}{l}\text { UDMA, dimethacrylatecomonomers } \\
\text { (Bis-GMA free), pre-polymerilized } \\
\text { silica/lanthanoid } \\
\text { fluoroaluminosilicate/silica }\end{array}$ & $\begin{array}{l}\text { G-premio bond (GC, Japan) 10- } \\
\text { MDP, 4-META, 10- } \\
\text { methacryoyloxydecyl dihydrogen } \\
\text { thiophosphate, methacrylate adic } \\
\text { ester, distilled water, acetone, } \\
\text { photo initiators, silica fine powder. }\end{array}$ \\
\hline Group 2 & $\begin{array}{l}\text { Estelite Bulk Fill flow } \\
\text { (Tokuyama, Japan) }\end{array}$ & $\begin{array}{l}\text { Bis-GMA, TEGDMA, Bis-MPEPP, } \\
\text { mequinol, dibutyl hidroxyl toluene, uv } \\
\text { adsorber, silicon oxide, zirconium } \\
\text { oxide }\end{array}$ & $\begin{array}{l}\text { Universal Bond (Tokuyama, } \\
\text { Japan) } \\
\text { Primer A: acetone, 3D-SR } \\
\text { monomer, MTU-6 (tiourasil } \\
\text { monomer),Bis-GMA, TEGDMA, } \\
\text { HEMA } \\
\text { Primer B: acetone, isopropanol, } \\
\text { purified water, borate cataylst, } \\
\text { peroksit, silan coupling agent } \\
\text { Futurabond U (Voco, Germany) }\end{array}$ \\
\hline Group 3 & $\begin{array}{l}\text { GrandioSO x-tra } \\
\text { (Voco, Germany) }\end{array}$ & $\begin{array}{l}\text { Bis-GMA, Bis-EMA, organically } \\
\text { modified silicic acid, aliphatic } \\
\text { dimethacyrlate }\end{array}$ & $\begin{array}{l}\text { Organic acids, functionalised } \\
\text { methacrylates, organic amine } \\
\text { compound, camphorquinone, } \\
\text { BHT, ethanol and water }\end{array}$ \\
\hline Group 4 & $\begin{array}{l}\text { Beautifil Bulk } \\
\text { Restorative } \\
\text { (Shofu, Japan) }\end{array}$ & $\begin{array}{l}\text { Bis-GMA, UDMA, Bis-MPEPP, } \\
\text { TEGDMA, fluoro-silicate glass (S- } \\
\text { PRG filler based on } \\
\text { fluoroboroaluminosilicate glass) } \\
\text { polymerization initiator, pigments and } \\
\text { others }\end{array}$ & $\begin{array}{l}\text { FL-bond II (Shofu, Japonya) } \\
\text { Primer: water, ethanol, carboxyl } \\
\text { acid monomer, phosporic acid } \\
\text { monomer and initiator } \\
\text { Bond: S-PRG filler based on } \\
\text { fluoroboroaluminosilicate glass, } \\
\text { UDMA, TEGDMA, 2-HEMA, } \\
\text { initiator }\end{array}$ \\
\hline Group 5 & $\begin{array}{l}\text { Fill-Up } \\
\text { (Coltene, Whaledent, } \\
\text { Switzerland) }\end{array}$ & $\begin{array}{l}\text { Dental glass, methacyrlates, } \\
\text { amorphous silica, zinc oxide }\end{array}$ & $\begin{array}{l}\text { ParaBond (Coltene, Whaledent, } \\
\text { Switzerland) Etchant Gel S: } 36 \% \\
\text { phosphoric acid } \\
\text { ParaBond A: methacrylates, } \\
\text { polyalkenoates, initiators } \\
\begin{array}{l}\text { ParaBond B: ethanol, water, } \\
\text { initiators }\end{array}\end{array}$ \\
\hline
\end{tabular}

Etching and bonding procedures were done according to the manufacturer's instructions. In group I, horizontal incremental layering technique was used to fill the cavity with G-aenial posterior (GC, Tokyo, Japan) microhybrid composite and light activation was done with LED light curing unit (VALO Cordless, Ultradent, USA, 1000 $\mathrm{mW} / \mathrm{cm}^{2}$ ) for 20 seconds. In group 2, Estelite Bulk Fill flow (Tokuyama, Japan) composite resin was placed in a single layer and polymerized with the 
same light source for 10 seconds. In group 3, GrandioSO x-tra (VOCO, Germany) composite resin was placed in a single layer and polymerized for 10 seconds. In group 4, Beautifil Bulk Restorative (Shofu, Japan) composite was placed in a single layer and poliymerized for 10 seconds. In group 5, Fill-Up composite resin was placed in a single layer and polymerized for 7 seconds. The restorations were then finished and polished (Astropol, Ivoclar Vivadent, USA) under abundant air water spray.

\section{Microtensile Bond Strength Test}

Specimens stored in distilled water at $37^{\circ} \mathrm{C}$ for 24 hours were placed on the sectioning device (Isomet 1000, Buehler, USA). Starting from the buccal side parallel to the long axis of the tooth, serial sections of approximately $1 \mathrm{~mm}$ width were taken under water cooling with a low speed diamond saw (ATM, Germany) in the buccolingual direction. The depth of the sections was extended to the crown-root junction. Then, serial slices were taken on the same sample starting from the mesial, approximately $1 \mathrm{~mm}$ wide. The teeth were cut along the cervical line perpendicular to the long axis of the tooth, resulting in rod-shaped sections of approximately $1 \times 1 \mathrm{~mm}$. At least 3 bonded stick shaped specimens were obtained from each tooth. The width of the sections was measured with digital micrometer and the dimensions were recorded. The microtensile bond strength test was performed using the universal test machine LF Plus (LLOYD Instruments, Ametek Inc. England). Each beam was attached to a custom made jig using cyanoacrylate glue (404 Kimya Sanayi ve Tic. A.Ş., Istanbul) and a tensile load was applied at a cross head speed of $0,5 \mathrm{~mm} / \mathrm{min}$ until the beam fractured. The amount of load required for fracture recorded in newtons was converted to megapascals (MPa).

After the microtensile bond strength test, the fractured specimens of all samples were examined by stereomicroscope (Nikon SMZ800, Tokyo, Japan) under x25 magnification. The failure mode (cohesive, adhesive, mix) was identified for each specimen.

\section{SEM Analysis}

After examination of all samples with stereomicroscope, fractured surfaces were evaluated in detail on SEM device (TESCAN MIRA3, Brno, Czech Republic).

\section{Statistical analysis}

The data obtained from this study were evaluated with one-way ANOVA and Tukey tests in SPSS 22.0 (SPSS Inc., Chicago, IL, USA) program.

\section{RESULTS}

The maximum and minimum microtensile bond strength values, mean and standard deviation of composite resins, the difference between groups are shown in Table 2.

Table 2. The maximum, minimum, mean and standard deviation values of the microtensile bond strength tests of the composite resins used in the study.

\begin{tabular}{|c|c|c|c|c|c|}
\hline Groups & $\mathbf{n}$ & Minimum & Maximum & $\begin{array}{l}\text { Mean } \\
(\text { MPa })\end{array}$ & $\begin{array}{l}\text { Standard } \\
\text { Deviation }\end{array}$ \\
\hline $\begin{array}{l}\text { Group } 1^{\text {a,b,c,dd }} \\
\text { G-aenial posterior }\end{array}$ & 15 & 23.03 & 36.90 & 29.573 & 3.50 \\
\hline $\begin{array}{l}\text { Group } 2 \text { a,e } \\
\text { Estelite Bulk Fill flow }\end{array}$ & 15 & 14.45 & 21.50 & 16.952 & 2.22 \\
\hline $\begin{array}{l}\text { Group } 3^{\text {b,f }} \\
\text { GrandioSO x-tra }\end{array}$ & 15 & 14.44 & 22.21 & 17.332 & 2.53 \\
\hline $\begin{array}{l}\text { Group } 4^{\mathrm{c}, \mathrm{g}} \\
\text { Beautifil Bulk Restorative }\end{array}$ & 15 & 14.37 & 19.95 & 16.444 & 1.77 \\
\hline $\begin{array}{l}\text { Group } 5^{\text {d,e,f,g }} \\
\text { Fill-Up }\end{array}$ & 15 & 11.10 & 15.73 & 13.426 & 1.57 \\
\hline
\end{tabular}

$\mathrm{F}=100.228 . \mathrm{P}=0.000 . \mathrm{p}<0,05$.

$\mathbf{a}, \mathbf{b}, \mathbf{c}, \mathbf{d}, \mathbf{e}, \mathbf{f}, \mathbf{g}$ there is a statistical difference between the groups shown with the same lower case letters. 
The control group showed the highest microtensile bond strength, while the Fill-Up group showed the lowest. G-aenial posterior composites showing the highest bond strength were followed by GrandioSO $\mathrm{x}$-tra, Estelite Bulk Fill flow and Beautifil-Bulk Restorative, respectively. When the control group was compared with four different bulk-fill groups, the difference was statistically significant $(\mathrm{p}<0.05)$. Among the bulk-fill composites, GrandioSO x-tra showed the highest bond strength; The differences between Estelite Bulk Fill flow and Beautifil Bulk Restorative were not significant $(p>0.05)$. Fill-Up group showing the lowest bond strength among bulk-fill composites, the difference between the other three bulk-fill groups was statistically significant $(\mathrm{p}<0.05)$. The most common type of failure is adhesive break across all groups. The least common type of failure is cohesive.

When the fracture surfaces of the G-aenial posterior were examined in SEM, inorganic structures attached to the dense organic matrix were observed on the dentin tubules (Figure 1).

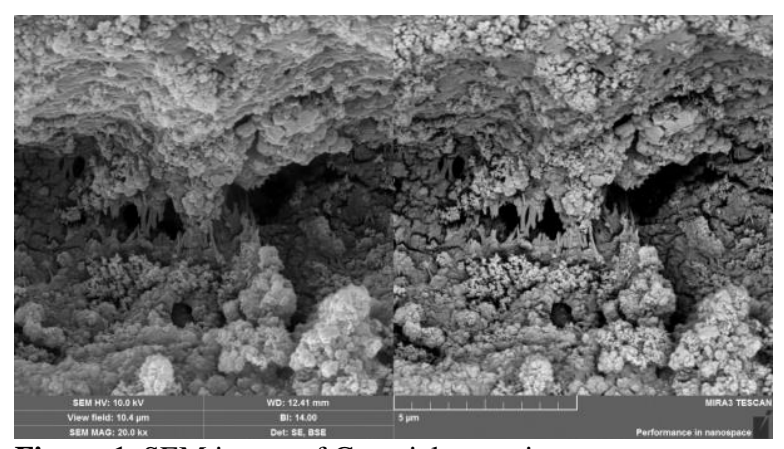

Figure 1. SEM image of G-aenial posterior

Estelite Bulk Fill flow had a distinct 0,5-1 $\mu \mathrm{m}$ gap along the hybrid layer on the fracture surface. (Figure 2).

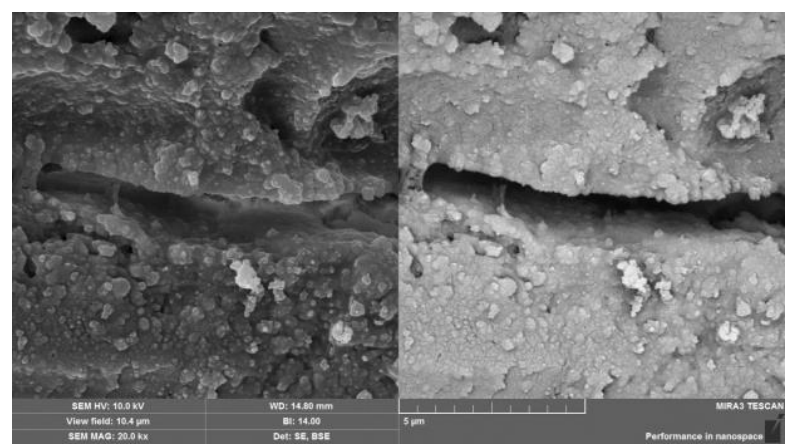

Figure 2. SEM image of Estelite Bulk Fill flow

Macro-resin tags detached from dentin tubules were also found on the fracture surface of GrandioSO x-tra (Figure 3).

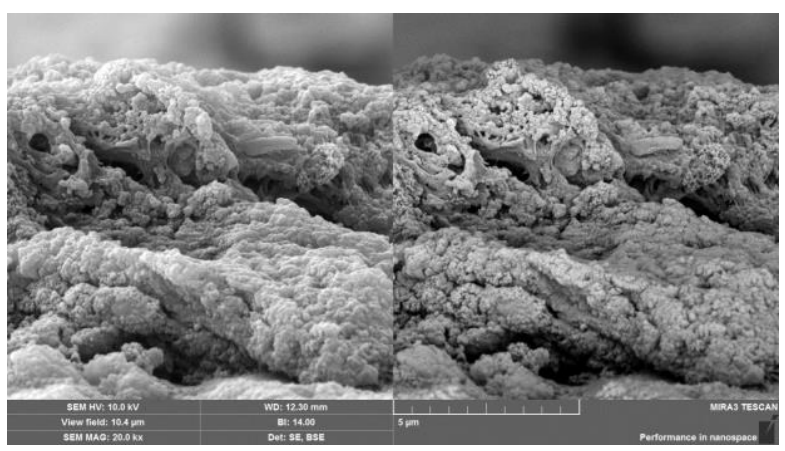

Figure 3: SEM image of GrandioSO x-tra

In the SEM image of the Beautifil Bulk Restorative, a complex plexus-like giomer matrix structure was observed (Figure 4).

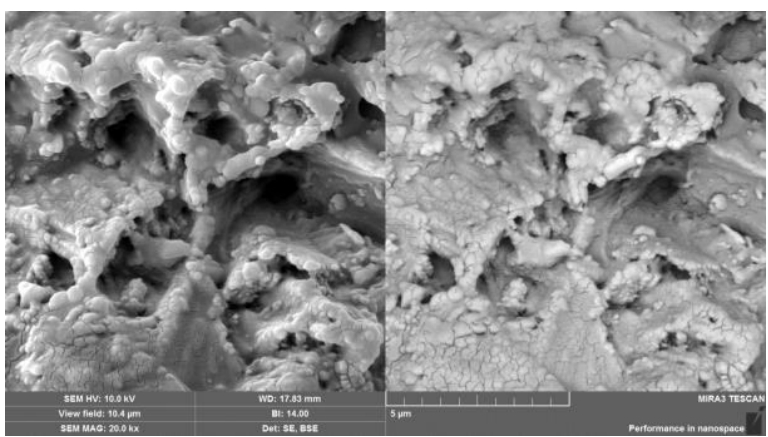

Figure 4: SEM image of Beautifil Bulk Restorative

When the fracture surfaces of Fill-Up were examined, it was seen that there were dilations due to demineralization in peritubular dentin canals (Figure 5).

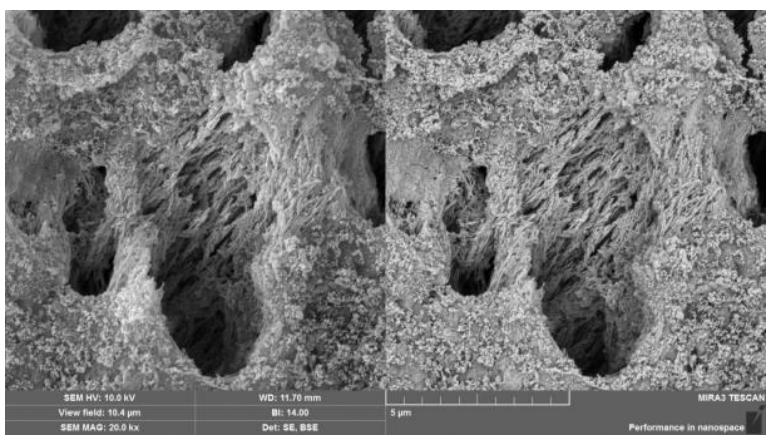

Figure 5: SEM image of Fill-Up

\section{DISCUSSION}

In order to spread the use of bulk-fill composite resins, their physical mechanical properties should be known and their bonding to dental tissue should be examined. The microtensile bond strength test applied in most research centers in recent years has many advantages that macro tests (conventional shear and tensile tests) cannot provide. Some of these advantages are; efficient use of teeth by obtaining multiple samples from a single tooth, the remaining dentin thickness to evaluate the effect of 
bonding, examination of tooth-induced changes, the assessment of the effect of resin-based composite bonding, more uniform force application than the conventional tensile test, the shape of the break can be easily determined by SEM. ${ }^{19}$

Among the four different bulk-fill and one microhybrid composite (control group) groups used in this study, the highest microtensile bond strength was determined by the control group, the microhybrid composite resin G-aenial posterior (G-premio bond) group. When the fracture surfaces of the G-aenial posterior group were examined in SEM analysis; Inorganic structures attached to dense organic matrix on dentin tubules support the conclusion that there is good bonding between composite and dentin. In the study of Çolak et al. ${ }^{20}$ evaluated the shear bond strength of 2 bulk-fill (SonicFill Bulk-Fill, Tetric EvoCeram Bulk-Fill) and 2 conventional nanohybrid composites (Herculite XRV Ultra, Tetric EvoCeram) to the middle coronal dentin in premolar teeth. As a result of the study reported that 2 nanohybrid composites exhibited higher values in terms of bond strength than bulk-fill composites. Although different composite types and bonding test methods are used in terms of material method; The study of Çolak et $a l$. is similar to this results when compared to this study. Almeida et al. ${ }^{21}$ studied the microtensile bond strength of 2 bulk-fill (Tetric Bulk Fill, SonicFill) and 1 conventional nanocomposite (Filtek Supreme XTE) in Class I cavities $(4 \times 5 \times 4$ $\mathrm{mm})$. Before the composite application, they applied etch and rinse adhesive system (Adper Single Bond 2) as a standard to all cavities. SonicFill shows the highest bond strength, followed by traditional composite and Tetric Bulk Fill was the lowest value. Almeida et al. ${ }^{21}$, although the different types of composites used and the use of a uniform adhesive system differed from this study, other results support this study except SonicFill. The highest microtensile bond strength in SonicFill can be associated with sonic activation technology.

When the fracture surfaces of GrandioSO $\mathrm{x}$ tra are examined in SEM analysis; the absence of open dentin tubules, the observation of irregular polymer structures with crater-shaped recesses on the composite surfaces, and the presence of very few macro resin tags detached from the dentin surfaces support a good bonding between the composite dentin.

Estelite Bulk Fill flow composite is distinguished from other bulk-fill composites by self-cured adhesive system. Although the microtensile bond strength test results of Estelite Bulk Fill flow (+ Universal Bond), which has a flowable structure, followed GrandioSO x-tra, which showed the best bonding among the bulk-fill composites in this study; the difference was not statistically significant ( $p>0.05$ ). When the fracture surfaces of Estelite Bulk Fill flow are examined in SEM analysis; observing a gap as if drawn with a regular pencil along the $0.5-1 \mu \mathrm{m}$ width hybrid layer may be associated with the application of a self-cured adhesive system. Further research is needed to clarify this situation.

Beautifil Bulk Restorative differs from bulkfill composites with its giomer structure. According to the results of microtensile bond strength test; Although Beautifil Bulk Restorative (+ FL-bond II) showed lower values than GrandioSO x-tra and Estelite Bulk Fill Flow, the difference between all three bulk-fill composites was statistically insignificant $(p<0.05)$. When the rupture surfaces of Beautifil Bulk Restorative were examined in SEM analysis; On the dentin tubules, unlike the other composites, there is a plexus-like complex giomer matrix structure.

Tsujimoto et al..$^{22}$ evaluated the polymerization depth and volumetric contraction of giomer bulk fillers (Beautifil Bulk Restorative, Beautifil Bulk Flow) and bulk fill composites (SDR, Filtek Bulk Fill Flowable, Tetric EvoCeram Bulk Fill, Filtek Bulk Fill Posterior Restorative). As the polymerization time was increased $(20,30,40 \mathrm{sec})$ in all the materials they used, the polymerization depth increased. Beautifil Bulk Flow showed the lowest polymerization depth among low viscosity materials; Among the high viscosity materials, Beautifil Bulk Restorative showed the lowest polymerization depth. Consequently, they report that giomers exhibit less polymerization depth than other bulk-fill composites. In terms of volumetric 
shrinkage, they reported that giomers showed more volumetric shrinkage than other bulk-fill composites in both low and high viscosity groups.

The fill-up bulk-fill composite resin differs from the other composites in this study by its dualcure polymerization and etch and rinse adhesives (+ParaBond). While in this study, Fill-Up bulk-fill composite showed the lowest microtensile bond strength, the differences between other composites were found to be statistically significant $(\mathrm{p}<0.05)$. When the fracture surfaces of Fill-Up were examined in SEM analysis; clear monitoring of dentin tubules using etch and rinse adhesive system and deep demineralization due to acid roughening of dentin may be related to lack of the simultaneous infiltration of the adhesive.

No literature has been reached to evaluate the bond strength of Fill-Up Composite. Monterubbianesi et al. ${ }^{23}$ studied the conversion degrees and microhardness values of 5 bulk-fill composites (Fill-Up, SureFil SDR, Filtek, SonicFill, SonicFill2). As a result of the analysis, a significant difference was observed between the lower surface of Fill Up and upper surface conversion degrees; reported no significant difference between the lower-upper surface conversion degrees of other bulk-fill composites. This difference Monterubbianesi et al. ${ }^{23}$ stated is consistent with the fact that Fill-Up showed low microtensile bond strength in this study.

Gupta et al. ${ }^{24}$ evaluated microleakage of 3 bulk-fill (Fill-Up, SonicFill, SureFil SDR) and 1 conventional (Filtek) composite in Class I cavities. SonicFill showed the most microleakage as a result of their study; Fill-Up followed this and SureFil SDR showed the lowest value. According to the study of Gupta et al. $^{24}$; The excessive microleakage of Fill-Up is compatible with the deep demineralization images of Fill-Up in this SEM images.

\section{CONCLUSIONS}

Bulk-fill composites did not show as good bond strength as conventional composite. When bulk-fill composites were used with their own adhesive systems, the bond strengths of other bulk-fill composites except Fill-Up were similar. Further improvement of the bulk-fill composites in terms of bond strength to dentin and follow-up clinical studies are essential for a complete evaluation.

\section{ACKNOWLEDGEMENTS}

This study was supported by the Sivas Cumhuriyet University Scientific Research Projects with the project code of DIS-214.

\section{CONFLICT OF INTEREST}

None.

\section{Sinıf I Kavitelerde Dört Farklı Bulk-Fill Rezin Kompozitin Dentine Mikrogerilim Bağlanma Dayantmlarının İncelenmesi}

\section{$\ddot{O} Z$}

Amaç: Çalışmamızın amacı, dört farklı bulk-fill kompozitin ve bir mikrohibrit kompozitin dentine mikrogerilme bağlanma dayanımlarının karşılaştırmalı olarak incelenmesidir. Gereç ve Yöntemler: Çalışmamızda 2 akışkan, 2 kondanse edilebilir bulk-fill kompozit ve bir mikrohibrit kompozit (kontrol grubu) kullanuldı. 25 adet yeni çekilmiş sağlam insan molar dişleri üzerine Sinıf I okluzal kaviteler hazırland, rastgele 5 gruba ayrlarak [G-aenial posterior $+G$ premio bond (Kontrol grubu), Estelite Bulk Fill flow + Universal Bond, GrandioSO x-tra + Futurabond U, Beautifil Bulk Restorative + FL-bond II, Fill-Up + ParaBond] her kompozit grubunun kendi adeziv sistemleri kullantlarak restorasyonlarl yapild. Restorasyonu tamamlanan dişler Isomet cihazlyla elmas testere yardımıyla bukkolingual ve meziodistal yönde kesitler alınarak her dişten üçer örnek olmak üzere her gruptan 15 örnek elde edildi. Çalışma gruplarına ait mikrogerilim bağlanma dayanım değerleri universal test cihazında ölçüldü, kuvvet birimi ise "newton” olarak kalibre edildi. Kopma yüzeylerinde meydana gelen mikroskobik değişiklikler Taramall Elektron Mikroskobunda incelendi. Veriler, istatistiksel yöntem olarak tek yönlü Varyans analizi ve Tukey testleri ile değerlendirildi. Bulgular: En yüksek mikrogerilim bağlanma dayanım değeri kontrol grubunda izlenirken, en düşük bağlanma dayanımını ise Fill-Up grubunda gözlenmiştir. Kontrol grubu, tüm bulk-fill grupları ile karşılaştırıldı̆̆ında fark istatistiksel olarak anlamlı bulundu (p<0,05). Bulk-fill kompozitler arasinda en yüksek bağlanma dayanımını GrandioSO x-tra grubu göstermesine rağmen, istatistiksel olarak karşılaştırıldı̆̆ında; Beautifil Bulk Restorative ve Estelite Bulk Fill flow grupları arasindaki farklar anlamsız 
bulunmuştur (p>0,05). Fill-Up grubu, diğer tüm bulk-fill gruplarıyla karşılaştırıldı̆̆ında aralarındaki farklar istatistiksel olarak anlamlı bulunmuştur $(p<0,05)$. SEM analizlerinde sadece Estelite Bulk Fill flow'da hibrit tabaka boyunca düzenli bir boşluk görülmektedir. Sonuçlar: Bulk-fill kompozitler, geleneksel kompozit kadar iyi bağlanma gösterememiştir. Bulk-fill kompozitler arasında Fill-Up etch and rinse adeziv sistemle kullanılmasına rağmen, en düşük bağlanma dayanımını göstermiştir. Anahtar kelimeler: Bulk-fill kompozit, mikrogerilim bağlanma dayanımı, dentin.

\section{REFERENCES}

1. Dresch W, Volpato S, Gomes J, Ribeiro N, Reis A, Loguercio A. Clinical evaluation of a nanofilled composite in posterior teeth: 12-month results. Oper Dent 2006;31:409-417.

2. Park J, Chang J, Ferracane J, Lee IB. How should composite be layered to reduce shrinkage stress: incremental or bulk filling? Dent Mater 2008;24:15011505 .

3. Petrovic LM, Atanackovic TM. A model for shrinkage strain in photo polymerization of dental composites. Dent Mater 2008;24:556-560.

4. Petrovic LM, Drobac MR, Stojanac IL, Atanackovic TM. A method of improving marginal adaptation by elimination of singular stress point in composite restorations during resin photo-polymerization. Dent Mater 2010;26:449-455.

5. Burgess J, Walker R, Davidson J. Posterior resinbased composite: review of the literature. Pediatr Dent 2002;24:465-479.

6. Ferracane JL. Resin composite-state of the art. Dent Mater 2011;27:29-38.

7. Lazarchik DA, Hammond BD, Sikes CL, Looney SW, Rueggeberg FA. Hardness comparison of bulkfilled/transtooth and incremental-filled/occlusally irradiated composite resins. The J Prosthet Dent 2007;98:129-140.

8. Ilie N, Hickel R. Investigations on a methacrylatebased flowable composite based on the SDR technology. Dent Mater 2011;27:348-355.

9. Moorthy A, Hogg C, Dowling A, Grufferty B, Benetti AR, Fleming G. Cuspal deflection and microleakage in premolar teeth restored with bulk-fill flowable resin-based composite base materials. Int J Dent 2012;40:500-505.

10. Vasquez D. A New Generation Bulk-Fill Composite For Direct Posterior Restorations. Inside Dentistry 2012;8:

11. Itota $T$, Carrick TE, Yoshiyama M, McCabe JF. Fluoride release and recharge in giomer, compomer and resin composite. Dent Mater 2004;20:789-795.

12. Dhull K, Nandlal B, Dentistry P. Effect of lowconcentration daily topical fluoride application on fluoride release of giomer and compomer: an in vitro study. J Indian Soc Pedod Prev Dent 2011;29:39.

13. Gordan VV, Mondragon E, Watson RE, Garvan C, Mjör IA. A clinical evaluation of a self-etching primer and a giomer restorative material: results at eight years. J Am Dent Assoc 2007;138:621-627.

14. Saku S, Kotake H, Scougall-Vilchis RJ, Ohashi S, Hotta M, Horiuchi S, Hamada K, Asaoka K, Tanaka E, Yamamoto E. Antibacterial activity of composite resin with glass-ionomer filler particles. Dent Mater 2010;29:193-198.

15. Murayama R, Furuichi T, Yokokawa M, Takahashi F, Kawamoto R, Takamizawa $\mathrm{T}$ ve ark. Ultrasonic investigation of the effect of S-PRG filler-containing coating material on bovine tooth demineralization. Dent Mater 2012;31:954-959.

16. Ünal M. The Comparison of Shear Bond Strenght of Different Bulk-Fill Composites to a Bioactive Dentine Substitute. CDJ 2018;21:274-283.

17. Buldur B, Öznurhan F, Kayabaşı M, Şahin F. Shear Bond Strength Of Two Calcium Silicate-Based Cements to Compomer.CDJ 2018;21:18-23.

18. Sakaguchi RL. Craig's Restorative Dental Materials. Elsevier Health Sciences, 2006.

19. Armstrong S, Geraldeli S, Maia R, Raposo LHA, Soares CJ, Yamagawa J. Adhesion to tooth structure: A critical review of "micro" bond strength test methods. Dent Mater 2010;26:e50-e62.

20. Colak H, Ercan E, Hamidi MM. Shear bond strength of bulk-fill and nano-restorative materials to dentin. Eur J Dent 2016;10:40-45.

21. Almeida Junior L, Lula ECO, Penha KJS, Correia VS, Magalhaes FAC, Lima DM, Firoozmand LM. 
Polymerization Shrinkage of Bulk Fill Composites and its Correlation with Bond Strength. Braz Dent J 2018;29:261-267.

22. Tsujimoto A, Barkmeier WW, Takamizawa T, Latta MA, Miyazaki M. Depth of cure, flexural properties and volumetric shrinkage of low and high viscosity bulk-fill giomers and resin composites. Dent Mater 2017;36:205213.
23. Monterubbianesi R, Orsini, G, Tosi G, Conti C, Librando V, Procaccini M, Putignano A. Spectroscopic and Mechanical Properties of a New Generation of Bulk Fill Composites. Front Physiol 2016;7:652.

24. Gupta SK, Mann NS, Kaur SP, Singh JP. Bulk fill vs Conventional Composites: A Microleakage Study. J Periodontal Med Clin Prac 2016;3:122-127. 